This item was submitted to Loughborough's Research Repository by the author.

Items in Figshare are protected by copyright, with all rights reserved, unless otherwise indicated.

\title{
'Passengers wishing to embrace this commodious conveyance, will apply immediately': the rise in emigrant passage advertising in the Scottish Borders, 1800-1830
}

\section{PLEASE CITE THE PUBLISHED VERSION}

http://dx.doi.org/10.1179/jrl.2008.4.1.21

\section{PUBLISHER}

(c) W. S. Maney \& Son Ltd

\section{VERSION}

AM (Accepted Manuscript)

\section{PUBLISHER STATEMENT}

This work is made available according to the conditions of the Creative Commons Attribution-NonCommercialNoDerivatives 4.0 International (CC BY-NC-ND 4.0) licence. Full details of this licence are available at: https://creativecommons.org/licenses/by-nc-nd/4.0/

\section{LICENCE}

CC BY-NC-ND 4.0

\section{REPOSITORY RECORD}

Beals, M.H.. 2019. "'passengers Wishing to Embrace This Commodious Conveyance, Will Apply Immediately': The Rise in Emigrant Passage Advertising in the Scottish Borders, 1800-1830". figshare.

https://hdl.handle.net/2134/19101. 


\title{
'Passengers Wishing to Embrace This Commodious Conveyance, Will Apply Immediately': The Rise in Emigrant Passage Advertising in the Scottish Borders, 1800-1830
}

\author{
M. H. Beals ${ }^{1}$
}

The use of newspapers in Scottish emigration studies is not new. Quotations from major papers were readily used in Allan Maclnnes' source book Scotland and the Americas. Aberdeen periodicals offered Marjory Harper's study of North-eastern emigration a better understanding the direction of migrant departure. Krisztina Fenyö used a broad base of periodicals in her 2000 study of public sentiment regarding the Highland Clearances. In fact, along with the Statistical Accounts, Scottish newspapers are some of the most oft-used sources for those delving into the Scottish migration. Historians have often used editors as gauges of popular sentiment, aligning them with particular classes or regions; Fenyö was particularly successful in doing this. However, this method concentrates on editorial content as a personal voice rather than a commercial enterprise, as this study intends to do. While a well-chosen quotation can clinch a historian's argument, these papers offer historians a much greater tool, if they are examined not only as a means to an end but as a form of expression themselves.

Although the periodical press was an important avenue of political and religious thought, by the late eighteenth century the press was in many respects a commercial animal. Whatever its political beliefs, whatever its stance on the morality of its neighbours, it needed advertising revenue. So, as

\footnotetext{
${ }^{1}$ The author would like to thank the staffs of the British Library at Colindale, the National Library of Scotland, and the Ewart Library in Dumfries, without whose aid this article would not have been possible. She would also like to thank the Faculty of Arts at the University of Glasgow for their financial support as well as Professor Edward Cowan and Dr. Colin Kidd for their encouragement of this project.
} 
the Scottish press matured, so too did the marketing material it contained. According to Hamish Mathison, between 1720 and 1780, Scottish newspaper advertisements became more numerous, frequent and sophisticated. The products offered in them became more varied, more often targeted at consumers rather than tradesmen, and advertising language and techniques evolved, utilizing tricks such as the faux open-letters to engage the reader's attention. As their importance grew, they crept from the back page further inward, eventually finding their place on the front. Furthermore, the advertisements were not just a supplementary source of income. They were in many respects the key to a paper's success. Advertisements, especially those directed at consumers, attracted readers to a paper, increasing its circulation, and the higher circulation numbers attracted the more advertisers willing to pay for space, the cycle spiralling, hopefully, to financial success. ${ }^{2}$

However, in the thirty year period between 1800 and 1830, Scottish papers were particularly scarce of emigrant-focused advertising. There were none of the notices for settlement supplies and few for the guidebooks that Harper found in the Aberdeen journals in later decades. Nor was there more than a handful of notices for foreign land or employment. These were just emerging in the 1820s, near the end of our period. Yet, Scots were emigrating, and private enterprise was not as apathetic as it may first appear. There was in fact one aspect of the emigration trade that was alive and well at the turn of the $19^{\text {th }}$ century-emigrant passage. By examining the evolution of these advertisements, so numerous and focused in the rural Border market, this study hopes to discover the relationship between supply and demand in this burgeoning trade. But we cannot study these advertisements in a vacuum. First, we must take a brief look at the papers that carried them.

\footnotetext{
${ }^{2}$ G. A. Cranfield, The Press and Society from Caxton to Northcliffe, Themes in British Social History (London: Longman, 1978), 179. Barker, Newspapers, Politics, and Public Opinion, p.185; H. Mathison, "Tropes of Promotion and Wellbeing: Advertisement and the Eighteenth-Century Scottish Periodical Press," in News, Newspapers, and Society in Early Modern Britain, ed. J. Raymond (London: Frank Cass Publishers, 1999). pp.207-209, 222; A. Walker, "The Development of the Provincial Press in England C. 1780-1914," Journalism Studies Vol. 7, no. 3. 2006; H. Barker, Newspapers, Politics and English Society, 1695-1855, Themes in British Social History (Harlow, England: Longman, 2000), pp.97. Barker, Newspapers, Politics, and Public Opinion, pp.159.
} 


\section{Scottish Newspapers}

In his 2006 introduction to a special issue of Journalism Studies on the provincial press, Andrew Walker laments that the historiography of early modern British papers relies far too heavily on a London-centric point of view, and that even newer works depend upon this 1960s groundwork. Despite this qualified criticism of newer works, the amount of scholarly research about the English provincial press is actually quite staggering, though the obligatory discussion scissor-and-paste journalism can make reading several in succession quite tedious. In terms of this study, however, the problem appears not to be that the historiography is London-centric, but rather England-centric, at least in terms of the late-eighteenth and early nineteenth century. ${ }^{3}$

Although many Scottish histories use and sometimes even depend upon newspapers for their source material, there exists very little information on the practices and development of the Scottish press itself, especially of country papers. Reading Cowan's 1946 study of The Newspaper in Scotland is a quick primer to some of the names and dates, but does not offer the sort of detailed insight needed to fully appreciate the content and reader divisions between the smaller country newspapers and their larger Edinburgh and Glasgow counterparts, nor the full web of connections between them. Fortunately, local histories from the Borders, as well as biographies of the editors, have shed considerable light on the subject and allowed this study to place the source material in a more concrete landscape. Furthermore, the foundation, style, and management of the English provincial presses seems to reconcile with that of the Scottish presses discussed here, and therefore the historiography has in most cases transferred neatly. ${ }^{4}$ It is hoped, however, that this subject will merit further attention in the future.

\footnotetext{
${ }^{3}$ A. Walker, op cit.

${ }^{4}$ The similarities between the late eighteenth and early nineteenth century presses was also recognized in Mathison, op cit. Because of the focus of this discussion is the period 1770-1830, and because most of the literature on English periodical suggests that a fundamental change in British journalism took place in the
} 
Despite the relative lack of historiography, southern Scotland, from Berwickshire to Wigtownshire, was well represented by newsmen by the turn of the nineteenth century. Although England had over 40 provincial papers in operation in 1782 , Scotland had only eight newspapers in total. Among these were the British Chronicle in Kelso, Roxburghshire, and the Dumfries Weekly Journal. With the foundation of Kelso Mail, Dumfries and Galloway Courier, and Berwick Advertiser before 1809, the Borders were home to five. Though their towns of residence do not all coincide with major centres, their readership stretched throughout the region, establishing a firm base for the conclusions of this discussion. ${ }^{5}$ To better understand the varied origins of these periodicals, however, a brief history of them is necessary.

The British Chronicle: Or, Union Gazette, credited by Kelso's Rev. J. M. MacCulloch as the first newspaper in the south of Scotland, was founded in the spring of 1783 with its original run lasting until 1803. Despite its wide circulation, contemporaries considered its editor, James Palmer, to be a radical. In response, the 'Tweedside Tories', as Cowan refers to them, invited James Ballantyne, an Edinburgh University law graduate and native of Kelso, to start a country paper of a more conservative political stance, a paper that far outlasted its cross-street rival. Not long after the Chronicle ceased publication, another Liberal paper appeared in the eastern borders, this time more removed from The Mail in Berwick. The British Gazette and Berwick Advertiser began its run in 1808 under Henry Richardson and 'steadily fought the landed interest-"the county gentlemen, flint taskmasters of the Government"'. A handful of other short-lived radical papers appeared throughout

\footnotetext{
later post-war years and at mid-century, I have relied primarily on discussion of eighteenth century journalism to compare these papers with the field as a whole. I have found very few discrepancies. For more on the historiography of the provincial press see especially $\mathrm{H}$. Barker, Newspapers, Politics, and Public Opinion in Late Eighteenth-Century England (Oxford: Clarendon Press, 1998); G. A. Cranfield, The Development of the Provincial Newspaper, 1700-1760 (Clarendon P, 1962).

${ }^{5}$ Many small papers rose and fell throughout the eighteenth century, but Drummond's estimate seems reliable for the papers available in 1782 . He is likely referring to the Caledonian Mercury, Edinburgh Advertiser, Aberdeen Journal, Dumfries Weekly Journal, Glasgow Herald, Glasgow Journal, Glasgow Mercury, and British Chronicle. Barker, Newspapers, Politics, and Public Opinion, p.95; A. L. Drummond and J. Bulloch, The Scottish Church, 1688-1843 : The Age of the Moderates (Edinburgh: Saint Andrew Press, 1973), p.148; Cranfield, op cit. pp.110-112.
} 
the 1820 s and 1830s, but The Mail and The Advertiser boasted the longest runs of the early nineteenth century. ${ }^{6}$

Along the Solway Firth The Dumfries Weekly Journal was founded in 1770 (thirteen years before The Chronicle) and published quite unimaginative clippings and summaries of the London news for the first years of its existence though maturing editorially before it disappeared in $1833 .^{7}$ Its lack of journalistic (and moralist) flair during the war with France led Henry Duncan, minister of Ruthwell, to found The Dumfries and Galloway Courier in the winter of 1809, acting as editor until 1816. Intended to offer 'weekly lessons of politics and morals' The Courier engaged its readers with a larger proportion of editorials and direct journalism than its eastern rivals, and though his editorials demonstrate paternal affection for the working classes, 'he invariably gave his hearty support to all that was valuable in the institutions of the country, to which he was, by principle and feeling, as well as by obvious interest, strongly attached.' Apparently as much a personal passion as a business, it was only after much deliberation that he chose a partner and successor to the editorship of The Courier, a man named M'Diarmid. The discussions engaged in and the sentiments expressed by both men were so similar that it is unlikely readers noticed any discontinuity in the handoff. ${ }^{8}$

Because the backgrounds of the early southern papers are so varied, the study is particularly blessed. Not only do the papers covers the entire period studied, their readership covers the entire geographic area and much of the socio-economic spectrum. The advertisements displayed in these

\footnotetext{
${ }^{6}$ For further details on the Kelso papers, see R. M. W. Cowan, The Newspaper in Scotland: A Study of Its First Expansion 1815-1860 (Glasgow: George Outran \& Co. Ltd, 1946), pp.11, 47-8; The New Statistical Account of Scotland. Vol. III: Roxburgh, Selkirk, Peebles (Edinburgh: William Blackwood and Sons, 1845), pp.343-344 and A. Moffat, Kelsae: A History of Kelso from Earliest Times (Edinburgh: Mainstream Publishing, 1985), pp.145-6. The Kelso Mail is available in bound copies at the National Library of Scotland. The Berwick Advertiser is available at the British Newspaper Library in London.

${ }^{7}$ For one of many scathing reviews of eighteenth-century provincial press standards, see Cranfield, op cit. p.179.

${ }^{8}$ For further details on the Dumfries papers, see G. J. C. Duncan, Memoir of the Rev. Henry Duncan, D.D., Minister of Ruthwell, Founder of Savings Banks, Author of Sacred Philosophy of the Seasons, \&C., \&C. (Edinburgh: W. Oliphant London Hamilton, Adams 1848), pp.77-78. and Cowan, op cit. pp.46-47. Both The Journal and The Courier are available on microfiche at the Ewart Library in Dumfries.
} 
papers were likely to reach a broad and representative base of Border Scots, either by subscription, reading room, or by word of mouth and communal reading. Furthermore, Barker argues that these provincial newspapers were able to command the loyalty of readers over larger ones in London, Edinburgh and Glasgow because readers based their subscription upon which town they most closely identified with economically and geographically, making these papers useful for gauging local demands. ${ }^{9}$ These advertisements will therefore help illuminate the changing tastes, needs, and demands for emigrant passage in the rural Borders and southwest regions of Scotland.

\section{Anatomy of an Advertisement}

Considered as a whole, the remarkable thing about the passage adverts between 1800 and 1830 is not their variety, though creativity was not lacking, but rather their curiously strict conformity. In the four regional newspapers which we shall discuss here, The Courier, Advertiser, Mail, and Journal, the editors all employed the same format to their passage adverts. ${ }^{10}$ This is curious because, first, the adverts for land, consumer goods and employment never followed such a strict pattern, even within a single issue, and second, those purchasing the advertisement space varied considerably in location, purpose, and financial standing. Yet, with only minor differences, advertisements of this sort were presenting in much the same way in Harper's Aberdonian papers. Clearly, it was a formula that worked.

This pattern is an enormous benefit to the historian and, most likely, to the original readership. Because of their consistent uniformity, they are easily spotted on the often cluttered advertisement pages and information such as destination, location and agent, are formulaically displayed, simplifying data analysis considerably. In every issue of all four periodicals, the reader, contemporary

\footnotetext{
${ }^{9}$ Barker, op cit. pp.134.

${ }^{10}$ The British Gazette lacked enough surviving issues to show any patterns in their advertisements, especially considering its run ceased before the significant push of 1816-1822.
} 
or modern, can easily scan the various options available, and compare and contrast with their particular needs.

The downside of using advertisements, especially such brief and uniform ones, is that the data they provide can become trivial and unrepresentative of the social trends they are meant to illustrate. Their use hides from view those providers who relied on word-of-mouth or other means of advertising to attract clients, thus limiting our ability to gauge the effectiveness of the various advertising techniques of which we have record. It also focuses our attention on data that in some ways is highly generic and perhaps only supplemental to outside information. Nonetheless, Stephen Lovell, in his discussion of Marriage Adverts, offers two counterarguments that apply as well as here as they do is his own study. First, though newspaper adverts can be unrepresentative of the entire marketplace, all other means obtaining this data are equally unrepresentative, relying on the preservation of personal records such as diaries, accounts book, memoirs and letters, which are piecemeal at best and often biased toward the middle and upper classes. Second, the advantage that lies in these adverts, as opposed to relying on editorial pieces is that despite their uniformity of structure they were at least partially written by individuals independent of the editorial staff and various traits particular to individual brokers and ship-owners do become apparent upon close inspection. $^{11}$

In order to better proceed with this study, a sketch must first be drawn of the archetypal passage advertisement to provide a constant point of reference. The regularity of the format throughout the period assures that our sketch will bear at least general resemblance to all the adverts which will be discussed. A passage advertisement contains six basic, invaluable components:

\footnotetext{
${ }^{11}$ S. Lovell, "Finding a Mate in Late Tsarist Russia: The Evidence Form Marriage Advertisements," Cultural \& Social History Vol. 4, no. 1. March 2007. p.53.
} 
The Image - A small engraving of a sailing vessel, which appeared in most of the advertisements with some exception toward the beginning or end of the period. A single engraving was used for notices regardless of the advertiser.

The Headline - The headline of the advert fell into two overlapping categories. Always in capitals and generally bolded or italicized, it was framed either 'For Passengers to [a continent]' or as a listing of the ports of call, or both.

The Hard Facts - The first (or only) paragraph detailed the sailing port, the destination, the name of the ship usually along with its captain, and the intended date of sailing.

The Marketing - The second half of the advertisement usually included marketable details such as reputation, amenities, or cross advertisements with previous or forthcoming sailings.

The Agent - The advertisement closed with directions on where to obtain further information and the name and premises of the ship's agent.

The Date - The last piece of information was a tagline with the origin and date of composition of the advertisement. This is particularly important as it allows the reader to recognize re-advertisements as well as amendments and updates.

Yet, the standardization of these six components affords us more assistance than merely the quick identification of the quantifiable details. The relative size and content of these six sections often changed subtly, sometimes dramatically, and these are clear indications of changes in marketing strategy by the ship owners, and thus an indication of changes in the demands of the emigrating population.

Although The Kelso Mail, The Dumfries and Galloway Courier, The Berwick Advertiser, and The Dumfries Weekly Journal were each examined in regard to advertisement frequency and content, statistical data presented in this discussion will be limited to The Mail and The Courier. Had The Advertiser and The Journal been included, the data would have been skewed significantly to the determent of historical enquiry. This is for two reasons. First, with a very few exceptions, neither the Advertiser nor the Journal carried any advertisements that were not identically and simultaneously carried by their regional rival. Second, the gross number of advertisements carried by these two papers was year to year less than their rivals, in some years significantly so. In general, only the 
largest concerns chose to advertise in both periodicals, and even they did so irregularly. ${ }^{12}$ Therefore, their inclusion would present two problems. It would give the occasional and mistaken appearance that a wider variety of advertisements were available to the region than was actually the case. Also, because the number of regional journals is so small, the lightly-advertised periodicals would skew any numerical averages taken, vastly under representing the marketing material presented to these audiences.

\section{Meeting the Rising Demand}

Most works on Scottish emigration from any period will preface their discussion with the idea that the Scots, as a people, have always tended toward emigration. They note that it had been a strong and consistent element of Scotland's culture centuries before the infamous Highland clearances and the mass migration of the mid-to-late nineteenth century. Studies of specific migrations in the later half of the eighteenth century only confirm this general trend. Census and genealogical sources confirm an ever-present if fluctuating flow of Scots abroad. This discussion, however, is not to trace the actual numbers and paths of individual Scots during this period, which has been illustrated by historians in increasing detail over the past forty years, but instead to trace the demand of the Border Scots for commercial emigrant passage, and the response of private enterprise to that demand.

Between 1800 and 1830, emigrant passage advertisements, here defined as notices offering passage to non-European ports, appeared in these four periodicals in a very predictable pattern. ${ }^{13}$ Despite

\footnotetext{
${ }^{12}$ The fact that the regional rivals shared a significant number of readers, as well as the fact that they printed on different days, suggests that local residents may have browsed both papers in order to keep with the latest London news. If this were the case, there would be little sense in publishing in both papers on a regular basis as this would result in as many as 3 adverts a week to a single audience. Barker, Newspapers, Politics, and Public Opinion, 125.

${ }^{13}$ Many of the advertisements, especially in the teens, advertised up to four ships from a single agent or ship owners. Because they were sailing at different times for different ports, and for the sake of clarity and consistency, each of these has been counted as a separate advertisement for statistical purposes.
} 
beginning their runs in the eighteenth century, it is not until 1802 that we get our first real taste of the emigrant passage business. Suddenly, talk of emigration was in the air and by the summer of 1803, several American ships were listed in The Mail as taking passengers from Glasgow to New York and Boston. But, just as suddenly, the advertisements disappear, the last running in February of $1804 .{ }^{14}$ Resumption of war with France and the danger of sea travel skyrocketing insurance rates (and customer fears) deflated the burgeoning market. ${ }^{15}$ This small burst in advertising, however, does signify something rather important. Hardly had the ink dried on the Treaty of Amiens before ships were prepared for commercial passage, setting sail at the next permissible season. In the decade of war with France demand for travel had evidently built up enough to require rapid attention from shipping concerns, many of who were already expanding their fleet to meet rising demands for North American timber. A web of ship-owners, agents, and subagents sprang up across Scotland and northern England to capture this valuable market. That they chose to advertise in local as well as national papers, and that they had local agents in inns and printers' officers, indicates that the supply was decentralized and the demand was high in rural areas and warranted the additional expenditure to capture this prospective market. ${ }^{16}$

Throughout the rest of the war years there were sporadic notices of passage, notably in The Advertiser and the Journal. These, however, were not for the type of commercial passage seen in later years from major ports such as London or Glasgow. Instead these ships, only a handful in number, sailed from Berwick and Dumfries to New Brunswick and the St Lawrence to purchase timber. Upon their return to Scotland, and having discharged their North American timber via advertisements earlier that winter, they offered to take on a few passengers, essentially as well-

\footnotetext{
${ }^{14}$ The Kelso Mail or, Roxburgh, Berwickshire, \& Northumberland Gazette, No. 636, 16 May 1803, No. 653,14 June 1803, No. 668, 5 September 1803. No. 715, 16 February 1804 Page 4.

${ }^{15}$ M. H. Beals, "Thinning Acquaintances: National, Familial, and Commercial Identity in the British Atlantic World, 1740-1840" Unpublished thesis. (Clark University, 2005), p.81.

${ }^{16}$ Harper, Adventurers \& Exiles: op cit. pp.121-122.
} 
paying ballast, for their return trip to Canada. ${ }^{17}$ These adverts were extremely brief, containing only basic information on when and where the ship would sail, sometimes joined onto the notice of timber sale. More importantly, the date of sail was less than a fortnight from the composition of the advertisement, giving prospective passengers no time to plan their journey or compare options. It appears instead to have appealed to those going on business or non-settlement journeys or single travellers able to quickly move their assets.

This brings us to 1815 and the real emergence of an emigrant passage market in the Borders. Napoleon's defeat at Waterloo brought a swift cease-fire on 4 July 1815 and an end to decades of war with France. At the next suitable season, spring of 1816, the Border papers were littered with advertisements for passage across the Atlantic to both British North America and the United States. Ship owners seemed to waste little time testing the waters for demand. In that year, nine adverts appeared in the spring issues of The Kelso Mail and nine in The Courier for a total of six individual voyages to North America (two Leith voyages being advertised in both papers). Though this number appears small, it represented advertising nearly equal to that of the previous ten years. By 1817 the number of advertised sailings had increased to over 20 and the marketing to a towering 80 advertisements, the highest number for the remainder of this period. Until 1821, with the except of 1820, the newspapers consistently ran about 50 advertisements a year (see Figure 1 and Figure 2) before reducing to a trickle of roughly ten a year for the rest of the decade. There was one last jump in 1825-26, but only in the Mail, and only for ships departing London. It appears that the initial postwar surge of local, self-financed emigrant travel had run its course in just over five years.

This sudden burst of activity was likely the result of the demand for westward passage that had been bubbling in Scotland during the wars with France and the United States. When the latter came to a close in 1814 , the $3^{\text {rd }}$ Earl of Bathurst, then Secretary of State for War and the Colonies, was well

\footnotetext{
${ }^{17}$ The British Gazetteer or Berwick Advertiser, No. 68, 15 April 1809, No. 75, 3 June 1809, No. 118, 31 March 1810, no. 130, 14 April 1810.
} 
aware of these rumblings and was concerned that once passage became available, Britons would flock to New York and Boston. The Secretary had no desire to increase a potential enemy's ranks with British ex-patriots. ${ }^{18}$ Instead, a plan for assisted emigration to British North America was formulated. Utilizing ships being sent to Canada to retrieve soldiers, the British government planned to assist 2000 Scottish emigrants (as well as 2000 Irish and 400 English settlers) with passage and land. Though the plan had to be delayed until the peace treaty was ratified by the United States Congress, and the appointment of a Scottish agent had not been finalised until the first week of March, advertisements for the scheme began to appear in the Scottish press by February of $1815 .^{19}$

It was a thoroughly conservative attempt at government-sponsored migration; the $£ 16$ deposit against jumping the border to the United States meant that only those that did not require such assistance would be able to obtain it. Nonetheless, there were several hundred Scottish applicants waiting for passage. When Napoleon returned to Paris in March 1815, the immediate need for Canadian troops meant that the ships could not wait to approve more applicants or to board the prospective emigrants. Obligated to those who had already secured assistance, and still concerned about the flow of Britons to the United States, Bathurst made sure the emigrants were given alternate passage that fall. Because they would arrive so late in the year, the settlers could not hope to make adequate preparations for the winter or the following spring. Hoping to secure praise from those writing home, Bathurst made arrangements with the military authorities at Rideau to temporarily lodge the settlers in a vacated military barracks and provided them with food and financial aid until they could establish themselves. Some received aid well into 1819. Bathurst's plan worked and many letters of praise were sent to Scottish families, encouraging them to join them in

\footnotetext{
${ }^{18}$ H. J. M. Johnston, British Emigration Policy, 1815-1830 'Shovelling out Paupers' (Oxford: Clarendon Press, 1972), p.17; M. E. Vance, "The Politics of Emigration: Scotland and Assisted Emigration to Upper Canada, 1815-26," in Scottish Emigration and Scottish Society: Proceedings of the Scottish Historical Studies Seminar University of Strathclyde 1990-91, ed. T. M. Devine (Edinburgh: John Donald Publishers Ltd., 1992), p.38.

19 Johnston, op cit. p.20.
} 
Canada. According to lists of assisted migrants, many of those writing home were from the borders, especially Dumfriesshire. ${ }^{20}$

Because most of the advertisements in The Mail were for Leith rather nearby Berwick or Eyemouth, its 'Shipping Intelligence' section sheds little light on how many Border Scots actually took up the offers of passage and any information gleaned from Edinburgh papers would not differentiate between the origins of those sailing. The editor of The Courier, however, was particularly interested in the spirit of emigration, and took great care in counting the number of passengers leaving aboard local ships, often detailing the home districts of the emigrants. It is from his 'Intelligence' that we know that nearly 300 passengers sailed aboard John Thomson's ships in 1817 (nearly 400 if you believe Thomson's own advertising) and several dozen others aboard Adam Rankine's vessels. Furthermore, the Dumfries shipping companies continued to bring roughly 350 settlers to Canada every year through the teens and into the early '20s. According to the editor, most of those boarding the Dumfries vessels were from Dumfriesshire, though some had come over from English border towns in Cumbria. ${ }^{21}$ Taking this into account, but also acknowledging that emigrants from the southwest also travelled to England, Glasgow or Dublin to obtain international passage, it is likely that at least 3000 Scots, near $2 \%$ of the regions population, emigrated from Dumfries and Galloway in the decade after Waterloo.

With such a demand, and with the government deciding not to repeat its assistance package the following year, it is little surprise that in the spring of 1816, private enterprise picked up the government's slack and provided private transport for those denied assistance. It is even less surprising that in the following years, when letters of praise began to arrive back home and the government again held out land in encouragement, that the demand surged. But what sort of ships

\footnotetext{
${ }^{20}$ Johnston, op cit. pp.18-21. T. McDonald, "'Come to Canada While You Have a Chance': A Cautionary Tale of English Emigrant Letters in Upper Canada," Ontario History Vol. XCl, no. 2. 1999. pp.113.

${ }^{21}$ Courier, No. 543, 18 April 1820.
} 
catered to this demand? As in the eighteenth century, and as it would be well into the midnineteenth century, the demand was most robustly met by ships primarily engaged in the North American timber trade. These merchants had enjoyed rather generous trade protection against Baltic competitors during the Napoleonic wars, but because of the high volume to value proportion of the timber, they needed a high-paying return cargo to make the trade viable. ${ }^{22}$ Passengers to the North American colonies were ideal for a variety of reasons. First, and most obviously, the merchants were going to North America regardless. Second, because of the relatively open cargo space needed to accommodate the timber, these ships were easily converted into passenger accommodation. They needed only to lay down beams at about five-and-a-half feet below the upper deck to create a lower deck in which they could lay two tiers of wooden berths along each side and possibly one down the middle. On a 400-ton vessel, this gave 200 passengers a very modest personal space of just six feet by six feet with no portholes or ventilation except the hatchways, which would be closed during rough weather. Nonetheless, the ships often received independent praise for their comfort. For such an easy conversion, and even at competitive fares, these emigrants represented a windfall profit to the timber traders, but, Harper contends, 'Passengers were seen as a bonus, rather than the sole justification for providing a vessel. ${ }^{23}$

\section{Marketing}

Nonetheless, the ship owners were not simply passive recipients of government leftovers; a policy of active marketing and sometimes aggressive competition had begun to emerge. The notices from the initial post-war boom are very different from those in the previous decade. In addition to the vital information of ship name, captain, and sailing port, more marketable details began to appear.

\footnotetext{
${ }^{22}$ M. Harper, Emigration from North-East Scotland: Volume One Willing Exiles (Aberdeen: Aberdeen University Press, 1988), p. 86.

${ }^{23}$ H. I. Cowan, British Emigration to British North America: The First Hundred Years (Toronto: University of Toronto Press, 1961), pp.144-6. On the comfort of the steerage accommodation, see D. C. Harvey, Journeys to the Island of St. John or Prince Edward Island: 1755-1832 (Toronto: The Macmillian Company of Canada Limited, 1955), pp.88-90. Harper, op cit., p.88.
} 
Simple phrases such as 'Very fine' ship and 'roomy' accommodation were the first additions, but within months the marketing sections of passage advertisements began to equal if not exceed the space allotted to the hard facts. A representative notice for passage to New York demonstrates:

\section{AT LEITH, FOR NEW YORK,}

(To succeed the SKEEN,)

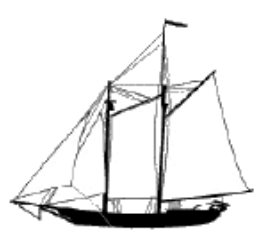

THE very fine coppered ship TRAVELLER, 400 tons burthen, THOMAS BELL, Master, will clear out on Monday the $1^{\text {st }}$ of July.

This Vessel having been for some time in Government service, for the conveyance of Troops, is admirably calculated for Passengers, having very high twixt decks, and well aired. Her Cabin is also fitted up in a superior style, and has every accommodation.

Passengers will require to be in Leith by Friday first or Saturday at furthest.

There is still room for a few more Passengers.

Apply to WILLAM ALLAN, Broker, Leith, June 22, $1816 .{ }^{24}$

Here the advertiser attempted to establish not only that his client had comfortable accommodation, but also experience in the passenger trade, thus making him superior to others bidding for the readers' attention. Different providers also began to compete by making direct reference to their rivals; Allan twice had to defend the Leith passage against ship owners from Workington who had declared it 'dangerous'. He noted spitefully 'that there can be no motive in making such representation, but to mislead the ignorant. ${ }^{25}$ Unlike the Highlands, where gentlemanly agreements over emigrant territory had been established, the Lowlands were fair game and fought over with great vigour. ${ }^{26}$ By the late teens, the number of ship advertisements appearing in each issue of the

\footnotetext{
${ }^{24}$ Mail, No 2004, 24 June 1816.

${ }^{25}$ ibid., No. 2301, 29 April 1819.

${ }^{26}$ Harper, Adventurers \& Exiles, p.122.
} 
Courier was so numerous that the editor opted to use to several different ship engravings in an attempt to break up the monotony of the front page. ${ }^{27}$

The universal use of such techniques shows a growing understanding of the need to appeal to customers' needs and consumer sensibilities. On the other hand, though the length and details of these advertisements grew significantly in the early decades of the century, they were still short and direct compared to those seen in Victorian Scotland. While contemporaneous products such as patent medicines and poetry collections used sophisticated techniques such as the full testimonial letter in their newspaper advertisements, this was not a feature of passage advertisements until a generation later. ${ }^{28}$ Because of the nature of passengers to these ship owners, high-paying ballast to their regular trade, this aspect of marketing had not yet fully evolved. Nonetheless, the clear difference between the advertisements of the eighteen-teens and a decade earlier shows that while emigrants may have been a bonus, they were a bonus worth fighting for.

In addition to more aggressive marketing, the ship owners began to allow more time for passengers to obtain information and passage. Rather than a single advert a fortnight before departure, the eastern Borders' papers averaged four adverts over as many weeks, the first usually being nearly a month before departure. In Dumfries they usually appeared for two or three weekly advertisements, although some had as many as six or seven, and the first usually appeared about twenty days before departure. Some advertised even further in advance: a Lothian agent gave notice that ships would sail from Leith for North America every 14 days in the summer of 1818, Dumfries advertisements reassured intending migrants that had missed their last ship that another would sail shortly, and a Kirkcudbright shipping company informed readers that it would arrive the next month, remain in port for a fortnight, and then continue on to America. ${ }^{29}$

\footnotetext{
${ }^{27}$ Courier, No. 390, 20 May 1817.

${ }^{28}$ Harper, Willing Exiles, pp.104-105; Mathison, op cit. pp.215-217.

${ }^{29}$ Mail, No. 430, 24 February 1818.
} 
Of course, 'passengers intending for North America' did not necessarily need the ship owners to inform them when passage would be available. In the post-war period, ships were advertised and sailed at regular times each year with advertisements usually beginning in late winter and continuing through the spring. Ships then departed in spring or early summer with April being by far the most popular month (see Figure 3 and Figure 4). The most aggressive advertiser in The Courier tried to take full advantage of the 'spirit of emigration' in 1817 and 1818 by rushing back for a second emigrant run in late summer. This timescale was employed by most of the timber-emigrant ships throughout the first half of the century, and coincided with the advice given in most guidebooks. ${ }^{30}$ Prospective emigrants could therefore make their plans well in advance of the sailing season and contemplate the various opportunities each spring. It was to some extent, therefore, a matter of whose ship had the best reputation, location or fare, rather than the most convenient timetable.

\section{Port of Departure}

In fact, location, from which harbour it set sail, is particularly important in reflecting the relationship between supply and demand. From the numerous published studies on Scottish emigration, this study may take for granted that a sizable number of Border Scots immigrated to North America, Australia, and Africa throughout the period studied here. ${ }^{31}$ These works, however, are unable to give a clear indication about the path most took to arrive at their final, recorded destination because of unavoidable flaws in their source material. Passenger lists and port records at either end do not always clearly indicate the precise origin of the traveller. Many list the last place of residence, which may hide those who travelled first to larger cities before deciding to emigrate, or the port of

\footnotetext{
${ }^{30}$ Harper, op cit. p.86.

${ }^{31}$ See, for example, D. Dobson, Emigrants and Adventurers from Southern Scotland. Pt. 1, The Scots Overseas (St Andrews: D. Dobson, 1994); S. J. N. Hornsby, "The Patterns of Scottish Emigration to Canada, 1750-1870," Journal of Historical Geography Vol. 18, no. 4. October 1992. pp.409, 412-413; D. Whyte, A Dictionary of Scottish Emigrants to Canada Before Confederation (Toronto: Ontario Genealogical Soc iety,1986)
} 
departure rather than their residence. ${ }^{32}$ Although Donald Whyte's A Dictionary of Scottish Emigrants to Canada Before Confederation does contain correlated information such as place of origin, passenger vessel, and place of settlement, the data is inconsistently available and, as the entire work represents only roughly $7 \%$ of all emigration to Canada before 1870 , cannot possibly provide us with conclusive answer our questions about the demand for local emigrant passage. ${ }^{33}$ Ideally, a combination of these two sources might shed significant light on matters, but such a study is unlikely because of the difficulty in matching individual emigrants. Passage advertisements therefore offer some much needed assistance. These papers often had a numerically wide readership within their own territory, but unlike larger London, Glasgow or Edinburgh papers were not directed at a national audience. Their advertisements instead often reflect an attempt to reach a very particular audience, in this case rural Border Scots and northern Englishmen, by addressing local enquiries directly. ${ }^{34}$

The papers attempted to market to a fairly wide area, including news not only from nearby Scottish, but also English counties across the border. Their area of influence, apparent from their news stories and the signatures of letters to the editors, seemed to stretch from the central belt of Scotland to the northern English counties of Northumberland and Cumbria. Longitudinally, however, even upon first inspection the patterns of port of departure point to a division along east-west lines. As mentioned above, The Advertiser rarely produced any advertisements that were not simultaneously in The Mail, the same being true of The Journal and Courier. This is noteworthy in itself. Considering the disparate editorship of the Advertiser and Mail, and to a lesser extent between the Courier and

\footnotetext{
${ }^{32}$ For more detailed information on the types of sources used to trace British Emigration to North America, see C. J. Erickson, "Emigration from the British Isles to the U.S.A. In 1831," Population Studies Vol. 35, no. 2. 1981.; C. J. Erickson, "Emigration from the British Isles to the U.S.A. In 1841: Part I. Emigration from the British Isles," Population Studies Vol. 43, no. 3. 1989. and Hornsby, op cit.

${ }^{33}$ Hornsby, op cit. p.398.

${ }^{34}$ Barker, op cit. pp.116, 125, 131; Courier, No. 496, 1 June 1819.
} 
Journal, the similarity of advertising suggests that the port of departure was determined more by geography than personal or business relationships between the editor and agent.

In the east, local ports were not favoured. Between 1809 and 1811, the Advertiser had offered two annual advertisements for direct passage from Berwick to Canada aboard returning timber ships. By the end of the war, however, these ships disappeared from the scene. In their place The Advertiser was home to a variety of ships marketed by a man named William Allan. Allan, offering the Borders over 20 different Leith ships between 1815 and 1830, was one of the most successful emigrant agents in the post-war period, scouring both the Highlands and Lowlands to obtain emigrants for ship-owners to fill their cargo holds. ${ }^{35}$

The Mail, a periodical much more popular with advertisers than its Berwick rival, had a similar story to tell. Between 1802 and 1816, the Mail offered no passage adverts from the Border ports. Instead, it occasionally offered information about the western port of Greenock. When peace ensued, and large scale advertising again began to appear, it was not Berwick, nor the Clyde, that captured the Mail's precious copy space. Like its rival, its most diligent and consistent advertiser was William Allan, joined now by half a dozen other Edinburgh shippers and agents. In fact, although it provided shipping intelligence for local ports, it only once displayed an advertisement for international passage from them; a single advert for an Eyemouth vessel in $1817 .{ }^{36}$ If Border vessels did obtain passengers from the Borders, they did not rely on periodical endorsement to do so. Instead, those wishing to leave from the south-eastern counties of Scotland relied on the established long-distance routes from the urban centre to their north.

\footnotetext{
${ }^{35}$ For Allan's highland exploits, see Harper, Adventurers \& Exiles, p.122.

${ }^{36}$ There were, however, several adverts for local or freight shipping along the east coast, especially to London and occasionally other European ports. The latter did allow a few passengers but cannot be classified as a international passenger vessel as defined for this study and was therefore not included in the discussion.
} 
In the west too, the timber traders were early recepients of westward travellers. Yet, unlike Berwick, the shipping links between the Solway Firth and Pictou only strengthed with the ending of the war, and, according to Edward Cowan, nearly all the Border Scots emigrating westward went through these ports. ${ }^{37}$ In the four most actively marketed years, Dumfries had nearly as many ships set sail as Leith, coming within three if all Solway ports are included (see Figure 5). The remaining ships sailed from Dublin, Glasgow, and Cumbria, all of which had frequent water communication with the Solway Firth. As with The Mail and The Advertiser, the western papers attracted advertisers from near their own coastline.

With the east-west divide firmly established, the question becomes, who decided the ports, supply or demand? While the practicality of sailing from the same coast as your residence cannot be denied, it is likely that the answer lies in part with the accesibility of the editor. In 1808, James Ballantyne, editor and owner of The Kelso Mail, left it to the management of his younger brother Sandy in order to pursue a more lucrative printing career in Edinburgh, and the eventual acquistion of the Edinburgh Weekly Journal. ${ }^{38}$ This family connection to Edinburgh would not have been uncommon, and perhaps suggests nothing in itself. However, in February 1826, Sandy Ballantyne gave up the printership of the The Mail and the paper saw a sudden shift toward adverts from London, Liverpool and Glasgow, with only two adverts appearing for Leith after $1825 .{ }^{39}$ In Dumfries, both papers remained steadfastly affliated with local shipping concerns, excepting Allan's occasional notices in the post-war boom. All this suggests that newspaper offices received advertisements from

\footnotetext{
${ }^{37}$ E. J. Cowan, "From the Southern Uplands to Southern Ontario: Nineteenth-Century Emigration from the Scottish Borders," in Scottish Emigration and Scottish Society: Proceedings of the Scottish Historical Studies Seminar University of Strathclyde 1990-91, ed. T. M. Devine (Edinburgh: John Donald Publishers Ltd., 1992), p.71.

${ }^{38}$ Though The Courier was partly funded by Duncan's brothers in Liverpool, this was not evident in the advertising section, unlike Ballantyne's Edinburgh connection. Duncan, op cit. pp.77-78.

${ }^{39}$ Cowan, op cit. p.47. Though a coincidental halt to Allan's business would also explain this change, William Allan and Son were still alive and well at the close of this period with a single advert appearing in the Mail in March 1830.
} 
ship owners and agents with whom they would have somewhat regular communication. ${ }^{40}$ Therefore, though they were somewhat agressive in their marketing to Border Scots, they do not seem to have gone far out of the way of their normal lines of communication to reach them.

Were any concessions made to these prospective migrants then? Was the demand for travel to British colonies from rural areas strong enough to obtain any extra consideration from the existing shippers? Did the passenger ships merely offer ballast space for would-be emigrants on their preestablished routes or did they take up new routes to accommodate a growing demand for commercial passenger traffic?

\section{Supply or Demand}

On the one hand, most of the advertisements in the Borders' provincial press were geared very specifically to passengers. $55 \%$ were specifically offering passage, $42 \%$ offered freight and passage, and $3 \%$ strictly advertised 'Passengers only'. Almost all boasted 'excellent accommodation 'being both 'very roomy [and a] full six feet high between decks.' Not only were the rooms newly fitted for passenger conveyance, including cabin passage, the crew was trained for such a service. Adverts included mentions of ship surgeons as well as indirect testimonials of customers. Notices also included settlement advice, or direction on how to obtain it, and prognoses on the Canadian job market:

The passengers who went by her to Ritchibucto last season, all got well employed immediately, and there can be little doubt but such as go this season will meet with similar encouragement, particularly Joiners, Blacksmiths, Farmers and Taylors. ${ }^{41}$

\footnotetext{
${ }^{40}$ Though The Courier received financial backing from Duncan's brothers in Liverpool, there were no advertisements for that port, despite its criticial role in the emigrant passage trade.

${ }^{41}$ Courier, No. 376, 11 February 1817.
} 
What is most important is that between 1800 and 1830, none of these papers offered solely freight services to international ports. The provincial press was often used as a trade journal and in port towns such as Dumfries we might be tempted to assume that a whole range of shipping activities would be advertised there. Up until the middle of the eighteenth century, the Scottish press had in fact relied on such trade advertising, but in the last quarter of the century the focus of advertising had moved firmly to consumer goods. ${ }^{42}$ Even in the port communities along the Solway Firth, and especially in the east, there seemed to have been no financial reason to advertise freight services. It was the emigrants, not the cargo, that interested the advertisers.

One the other hand, the passages advertised in The Courier between 1815 and 1821 seem to indicate that these ships were remaining in their pre-established routes. $60 \%$ of the advertised sailings followed the timber laden Solway-Canadian route. $8 \%$ travelled around the Cape of Good Hope from Leith, all in the years $1820-1$, and $28 \%$ were to the major US ports. The US-bound ships were divided among the ports, half travelling from Dumfries, a third from Glasgow, and the rest split between Dublin and Leith. Of these, only the seven Dumfries-US sailings fall outside expected patterns. However, as they set sail at the height of the spirit, were from the larger timber shipping firms and would lose little time stopping over in New York on the way to the St Lawrence, these sailings fail to indicate any real shift away from the established timber trades routes.

Advertising in The Mail was more evenly split. For the same period The Mail had $14 \%$ of sailings for Australia via the Cape of Good Hope, 34\% for the United States, and 51\% for Canada. This is likely the result of the type of advertiser working with The Mail. Unlike The Courier, which principally held adverts from two major shippers, The Mail along with The Advertiser mainly took those brokered by William Allan but from a constantly changing list of shippers; of the 27 adverts placed by him only 3 ships engaged his service a second time. Other repeated advertisers were agents of the Canada

\footnotetext{
${ }^{42}$ Mathison, op cit. pp.207-8.
} 
Company in Glasgow and London brokers, including John Pirie \& Co. Of London. Pirie became one of the principal shippers of assisted emigrants to Australia $1830-1850$ but at this time was sailing predominantly to India. ${ }^{43}$ As these ships sailed from major British ports, predominately Leith, Greenock, Liverpool and London, and the five cases of ship repetition were by agents or large metropolitan shipping concerns, it is unlikely that any of them represented a true emigrant passage business. It instead suggests that Allan made a good living filling up the unused space of the ships departing Leith, and found a convenient market in the eastern borders.

As some of the other men did become heavily involved in emigrant passage in the following decades, however, it is crucial to differentiate between that business and that of the eighteen-teens and twenties. In his 1982 article on the role of Private Enterprise and the Peopling of Australasia, Broeze notes that the financial advantage to firms in the mid-nineteenth century was not primarily from the fares derived from the passage, but instead from the enriching of their trade routes by increasing commercial demand in the colonies. Not only would the original migration increase the colonial population, but it would also increase the rate in chain migration to these ports. As each of these settlers was a guarantee of roughly $£ 10$ a year it was well worth the effort and cargo space to increase their numbers. ${ }^{44}$ His discussion focused on the period after 1830, but by 1820 Leith had already begun advertising passage to these under-peopled ports. However, unlike the large scale movements Pirie and others would later operate, notices for these ports in The Mail were only popular 1820-1821 and completely absent from their west coast contemporaries. Demand implied by epilogues such as 'Several Passages being already engaged, early application will be necessary 'were either short lived or fictitious. Furthermore, while Broeze's model is somewhat applicable to the early passages around the Cape and to a lesser extent the still thinly populated British North

\footnotetext{
${ }^{43}$ F. J. A. Broeze, "Private Enterprise and the Peopling of Australasia, 1831-50," The Economic History Review New Series Vol. 35, no. 2. 1982. pp.237-238.

${ }^{44}$ ibid. p.240.
} 
America, it cannot account for the passages to the United States that comprised over a quarter of advertisements in the eastern borders. It is therefore unlikely that the shippers saw future profits from consumerism as their main motivation, even if that was an eventual result. Instead, as with the earlier Berwick timber merchants, the demand for passage was seen as a useful way to fill ballast and unused cargo space.

So, for all the growing editorial hype over the fertile lands of Australia and Africa, and the financial encouragement to settle in British North America, the United States was still the destination of choice for a sizable majority of the passengers departing from the Borders. Even those taking ships to British North America were more likely than not to skip over the border at the first opportunity. ${ }^{45}$ The shippers knew this and planned accordingly. Although both William Allan and Glaswegian agents gave some information about settlement in Canada, agents throughout the Borders seemed to know that their best chance at attracting passengers was to appeal to those heading further south. Larger ports could offer passage on their direct commercial lines to northern United States cities such as Boston, New York and Philadelphia. That these were just following existing commercial routes is illustrated by the rarity (only one concern) of passage to Virginia, whose commerce with Britain had rapidly declined after the American Revolutionary War and especially after $1812 .^{46}$ Smaller ports also tried to compete for US-bound passengers: Thomson provided ships for Philadelphia and John Carruthers of Dumfries offered passage for Boston, drawing attention to the fact that 'There is seldom an opportunity from this port to the United States, and at so seasonable and convenient a time of the year. ${ }^{47}$ Others marketed with the hand they were dealt. Their timber trade obligations meant they would be travelling along the St Lawrence River, but several advertisements explained that 'as a ready and moderate conveyance is always to be got from St. John's into any Port of the

\footnotetext{
${ }^{45}$ Johnston notes this in op cit. pp 25-6 and it seems to be easily confirmed by letters and advertisements presented in the Border newspapers. For an example, see Mail, No. 2671, November 14, 1822.

${ }^{46}$ Beals, op cit. p.129; K. Morgan, "Bristol and the Atlantic Trade in the Eighteenth Century" English Historical Review Vol. 107, no. 424. 1992. P.629.

${ }^{47}$ Courier, No. 496, 1 June 1819.
} 
United States, it may be interesting to passengers who wish to go that way to embrace the present opportunity. ${ }^{48}$ When the British Government altered the Passenger Act and allowed a larger number of passengers per ton aboard Canadian-bound vessels, timber traders could further sweeten the deal by offering a reduction in fares.

The Scots who dreamt of foreign shores were not merely fare-paying ballast with no say in the service provided. The demand for travel to North America, and to a lesser extent to Africa and Australia, was a powerful force in first decades of the nineteenth century. That these ships were filled and even sometimes overbooked demonstrates that the borders offered sizable profits to those willing to convert their holds and cabin space. Furthermore, the often aggressive marketing between firms and shorelines meant that shippers were willing to fight over the finite number of unassisted migrants the south had to offer. Nonetheless, commercial language and freshly-installed bedding aside, the owners were not actively in the emigrant passage business, as they would not be until much later in the century. Neither their routes nor their circles of commerce changed greatly during the period. They seemed happy to accommodate and take advantage of the spirit but were not at all ready to submit fully to the demands of the emigrants over their established freight businesses.

The rise of passage advertising in the early nineteenth century was not, of course, restricted to the Borders of Scotland. By mid-century, Great Britain was teeming with provincial papers and advertisers, many with the same number of ship notices as the Mail and Courier, if not many more. This study has shown the feasibility and advantage of examining these advertisements to gauge popular interest and, in conjunction with other statistical and qualitative sources, to gain a better understanding regional rates and paths of migration. Heretofore, historians have in many cases relied upon genealogical resources and shipping records to piece together the general movement

\footnotetext{
${ }^{48}$ ibid. No. 388, 6 May 1817.
} 
trends of the early nineteenth century. It is hoped that this method of commercial analysis will illuminate contemporary opinions about these paths-for example, which were deemed typical and which were considered risky-and better trace regional variations. Expanding this study to Scotland or Britain will assist the mapping of emigration in this under documented period, one before largescale assistance programmes and steam travel, where effective census taking was just beginning and where the movement of small groups and individuals makes quantitative analysis particularly difficult. 
Figure 1: Number of Individual Advertisements By Year: 1816-1821

Source: Kelso Mail or, Roxburgh, Berwickshire, \& Northumberland Gazette 1816-1821; The Dumfries \& Galloway Courier 1816-1821

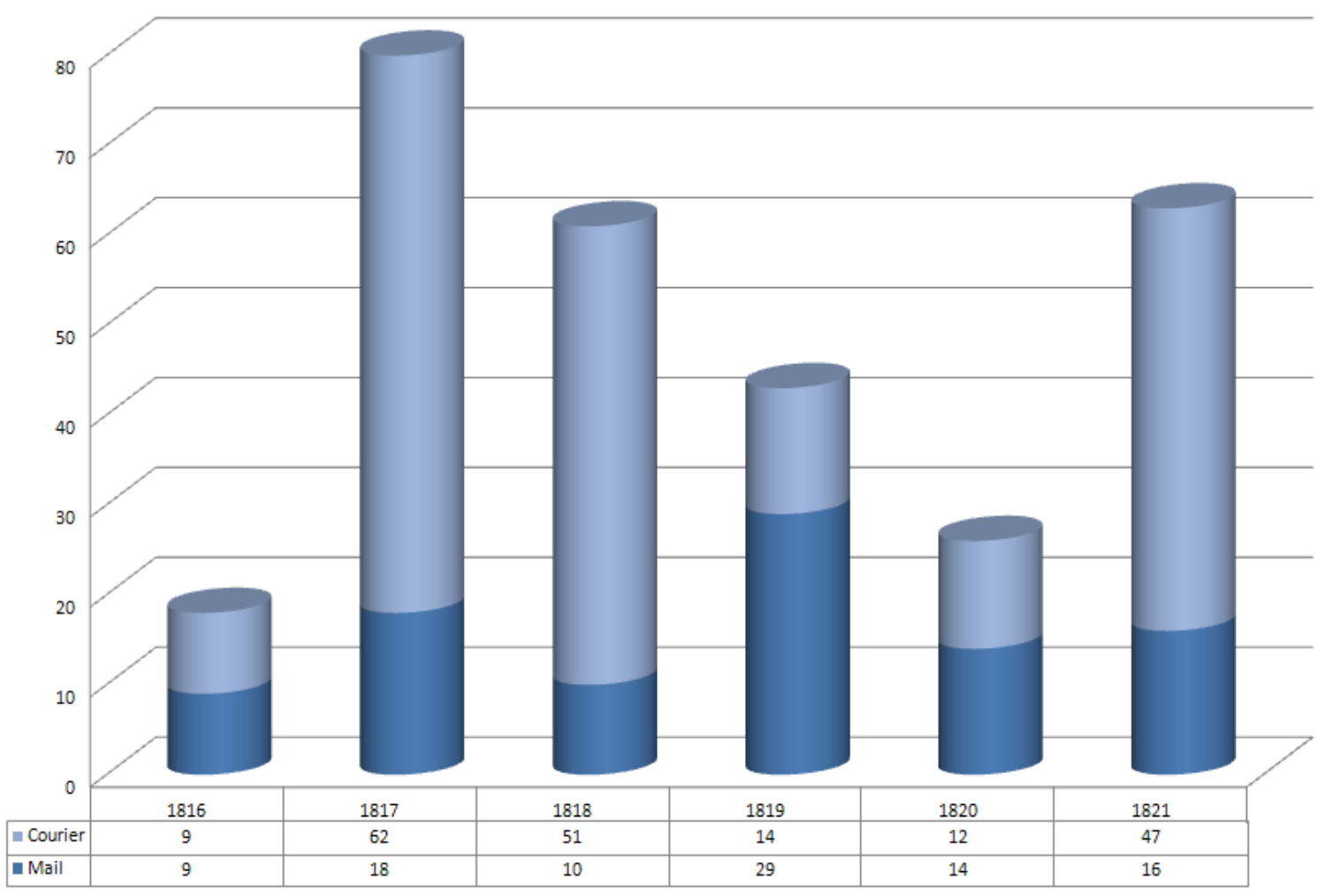

Figure 2: Number of Individual Sailings By Year: 1816-1821

Source: Kelso Mail or, Roxburgh, Berwickshire, \& Northumberland Gazette 1816-1821; The Dumfries \& Galloway Courier 1816-1821 


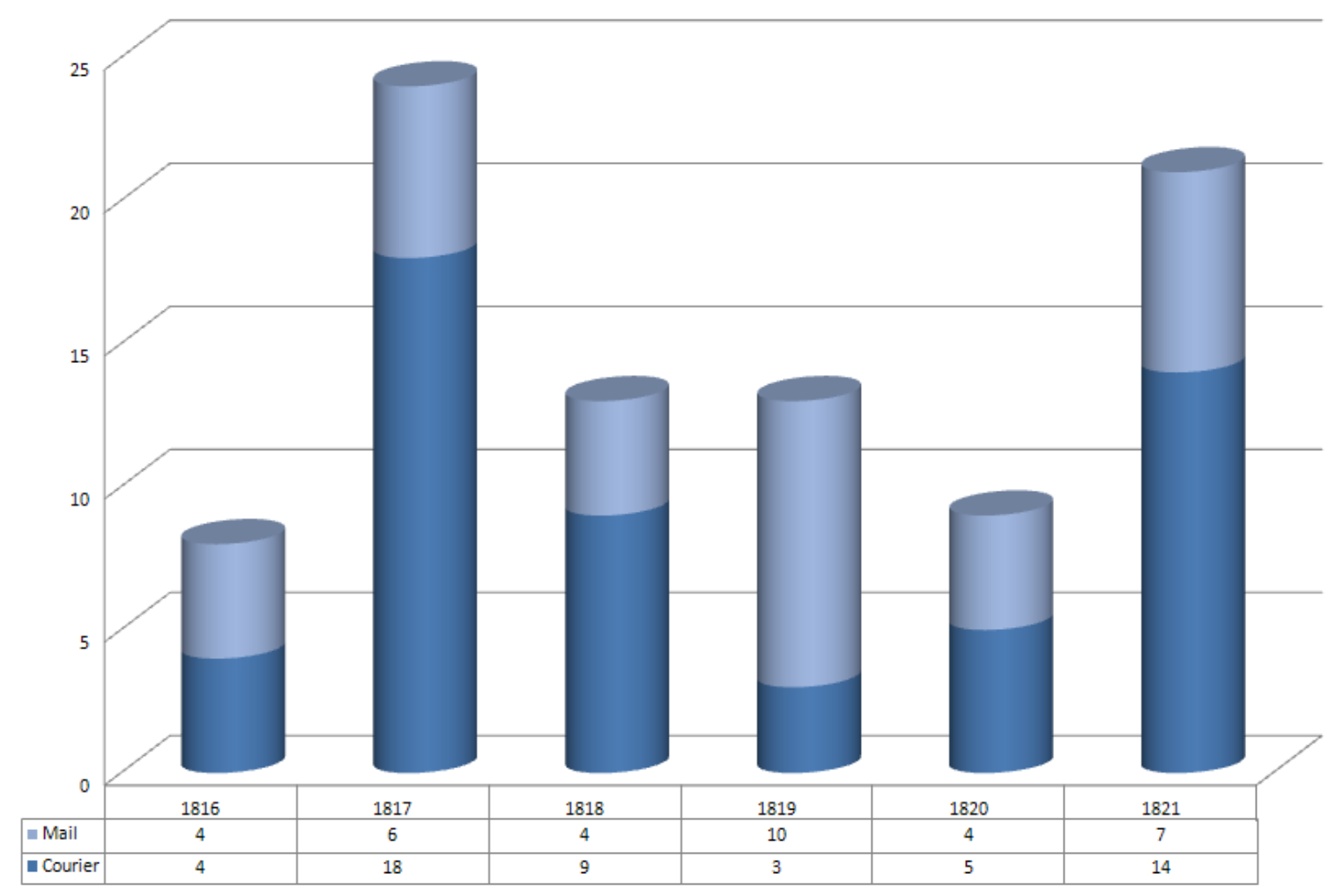

Figure 3: Number of Advertisements By Month: 1816-1821

Source: Kelso Mail or, Roxburgh, Berwickshire, \& Northumberland Gazette 1816-1821; The Dumfries \& Galloway Courier 1816-1821 


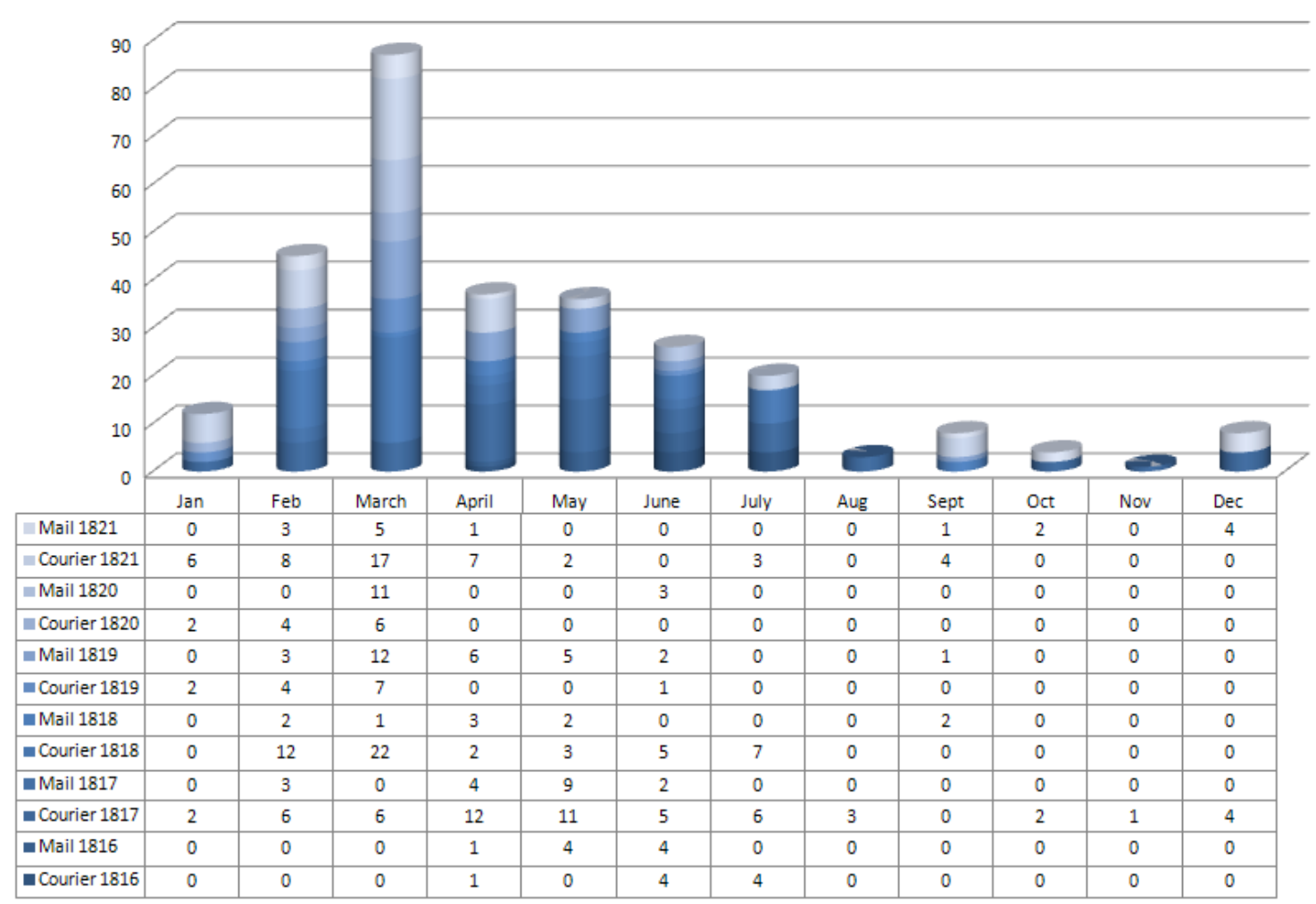

Figure 4: Number of Individual Sailings By Month: 1816-1821

Source: Kelso Mail or, Roxburgh, Berwickshire, \& Northumberland Gazette 1816-1821; The Dumfries \& Galloway Courier 1816-1821 


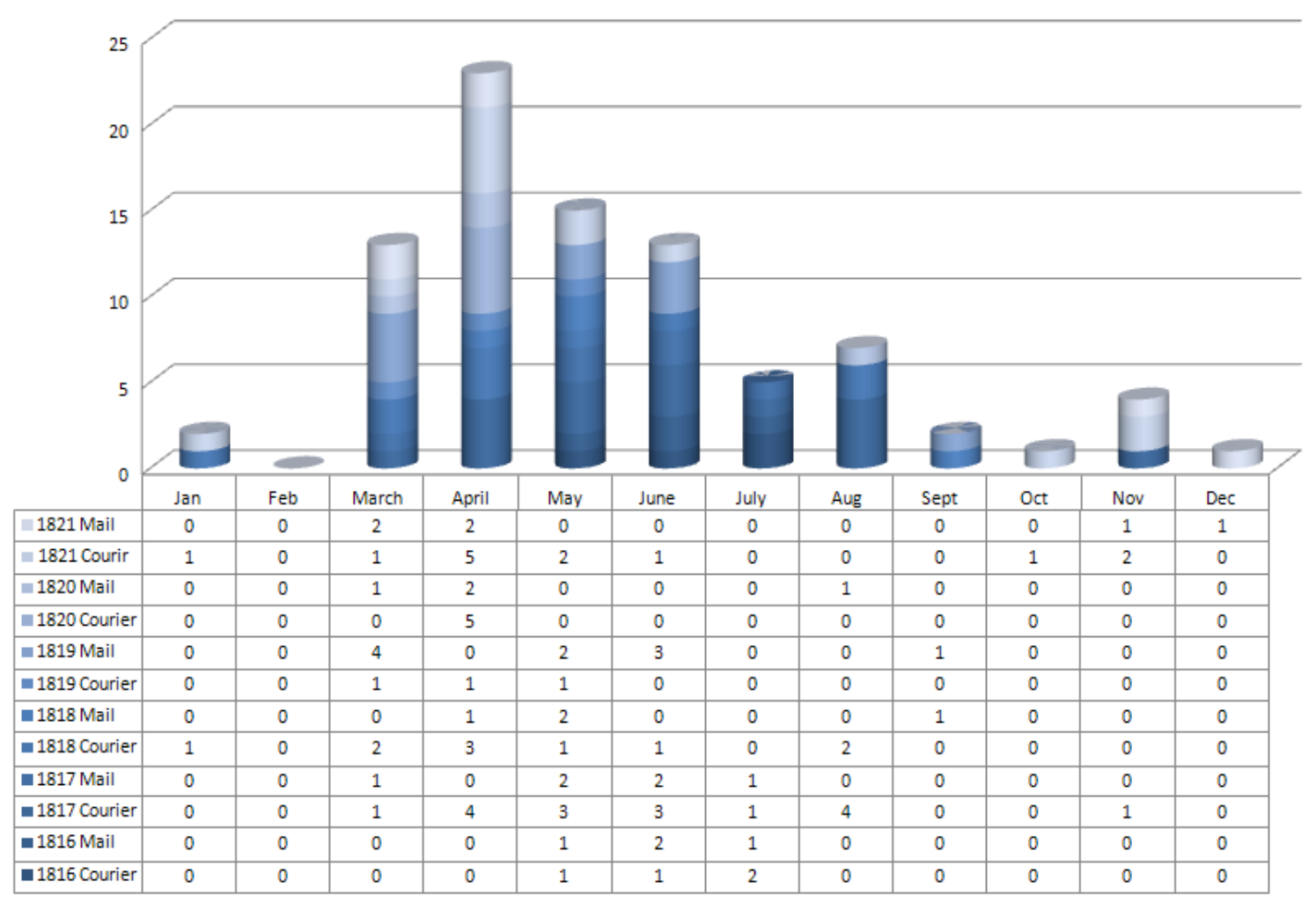

Figure 5: Number of Individual Sailings By Port of Departure: 1816-1821

Source: Kelso Mail or, Roxburgh, Berwickshire, \& Northumberland Gazette 1816-1821; The Dumfries \& Galloway Courier 1816-1821 


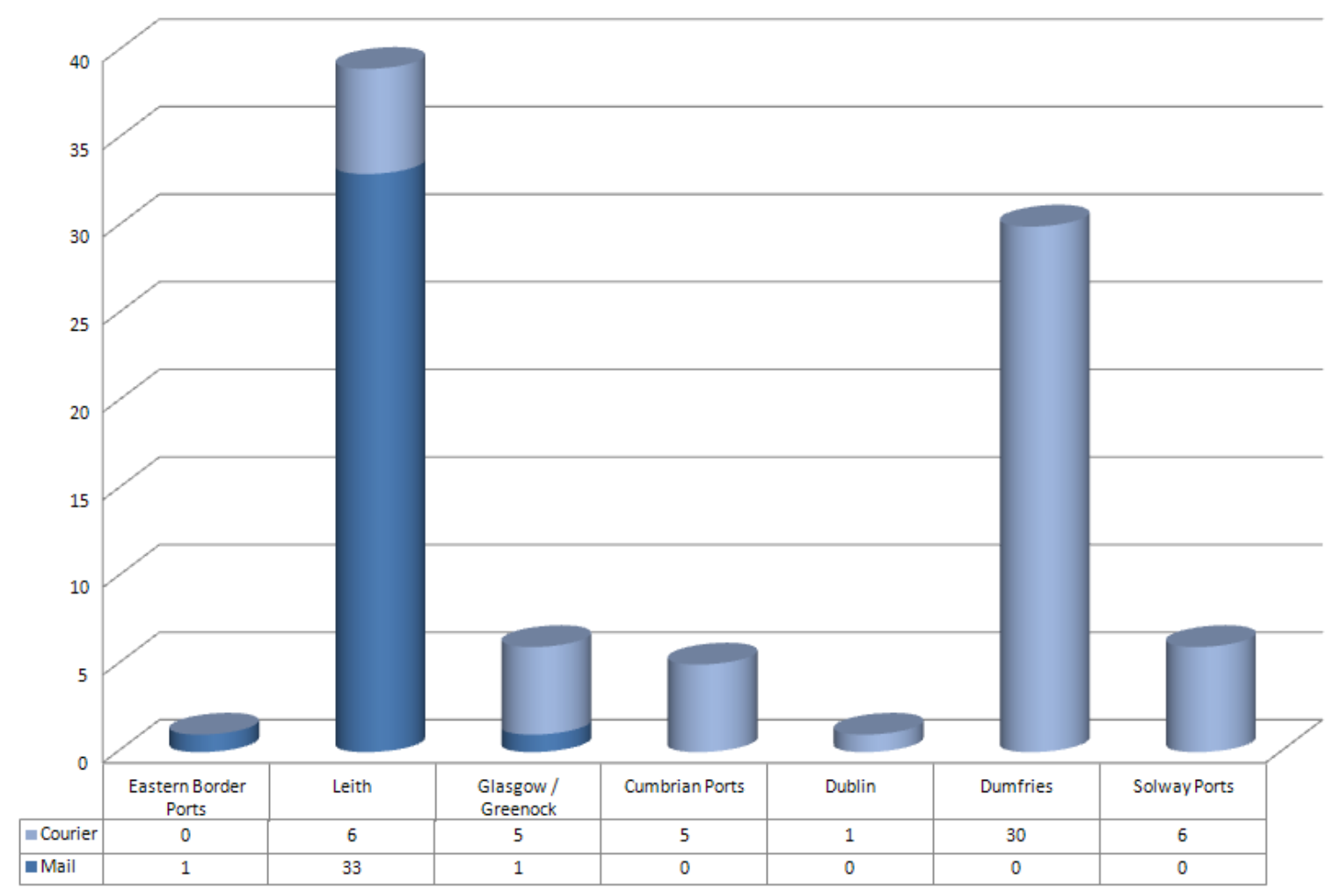

